\title{
A case of hemangiopericytoma of the buccal mucosa
}

\author{
Masaaki Terakado ${ }^{1}$, Tamotsu Uehara ${ }^{1}$, Tomiyuki Takigawa ${ }^{1}$, \\ Masahiko Honda ${ }^{1}$, Hidero Ohki ${ }^{1}$, Tadanobu Sekiwa ${ }^{1}$, Hiroshi Sato ${ }^{1}$, \\ Ayako Kawashima ${ }^{2}, K_{\text {Kazuo Komiyama }}^{2}$ and Itaru Moro ${ }^{2}$ \\ Departments of Oral and Maxillofacial Surgery ${ }^{1}$ and Pathology ${ }^{2}$, Nihon University School of Dentistry
}

(Received 24 July and accepted 10 November 1997)

\begin{abstract}
We report a 46-year-old woman who presented with a hemangiopericytoma in the buccal mucosa. At the 2-year postoperative examination, there was no evidence of recurrence or metastasis. The findings in the present case are compared with previous reports in the Japanese literature, with regard to patient age and sex, and lesion size, location, malignancy, local recurrence and metastasis.
\end{abstract}

Key words: hemangiopericytoma; buccal mucosa; pericyte.

\section{Introduction}

Hemangiopericytoma was first described by Stout $e t$ al. (1) in 1942 as a vascular tumor originating from the pericyte, a perivascular modified smooth muscle cell.

Hemangiopericytoma can be found at any site of the body where pericytes are present, and affects mainly adults at deep locations such as the soft tissue of the lower extremities, pelvic peritoneum, retroperitoneum and orbit (2). This tumor rarely occurs in the oral cavity (2).

Hemangiopericytoma is commonly benign in nature, but local recurrence and metastasis may be observed occasionally $(3,4)$.

The present report describes an unusual case of hemangiopericytoma which developed in the left buccal mucosa, along with a review of the Japanese literature (3,5-30) concerning hemangiopericytoma of the oral region.

\section{Case report}

A 46-year-old Japanese woman presented with a 2year history of a small painless mass on the left buccal mucosa corresponding to the first and second molars (Fig.1). She was referred to our hospital because of gradual enlargement of the lesion. Otherwise, her medical history was unremarkable.

Physical examination revealed a walnut-sized mass with an indistinct border on the buccal mucosa. The covering mucosa was normal in appearance except for tooth compression marks at the top of the mass (Fig.2). The regional lymph nodes were not palpable.

Correspondence to Dr. Masaaki Terakado, Department of Oral and Maxillofacial Surgery, Nihon University School of Dentistry, 1-8-13 Kanda-Surugadai, Chiyoda-ku, Tokyo 101, Japan
CT examination revealed a round mass showing density similar to that of muscle in the submucosal area of the anterior portion of the left mandibular ramus (Fig.3).

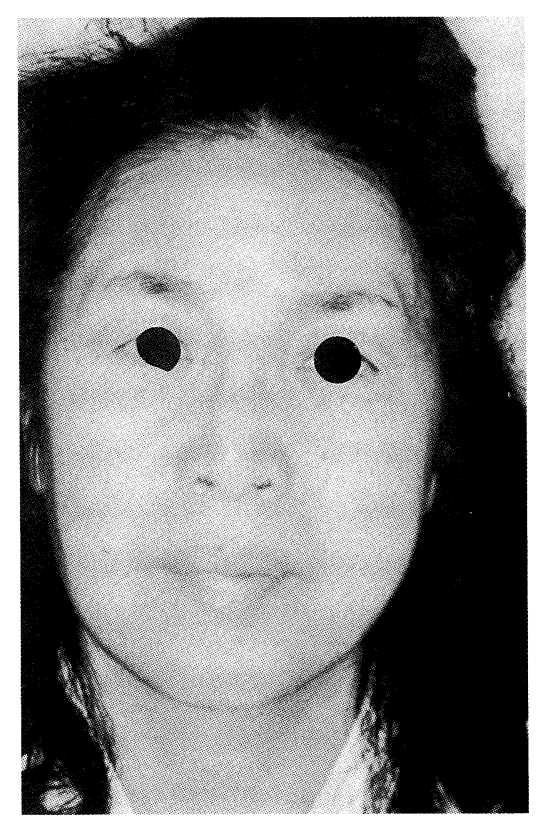

Fig. 1 Slight bulging of left check.

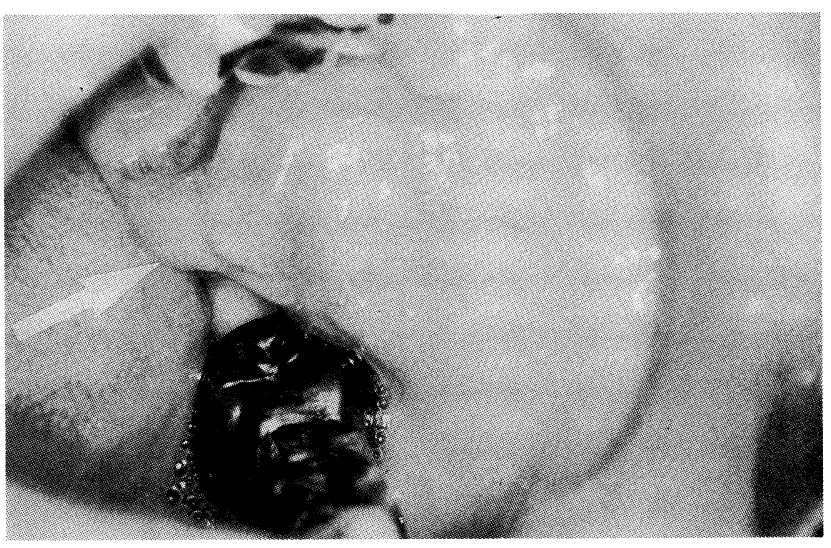

Fig. 2 Hemispheric bulging showing compression by teeth. 
The patient underwent surgical excision of the mass. The lesion was well demarcated from the surrounding tissue. Histologic examination revealed that the excised mass was approximately $2.5 \mathrm{~cm}$ in diameter and well encapsulated by reddish fibrous tissue (Fig.4).
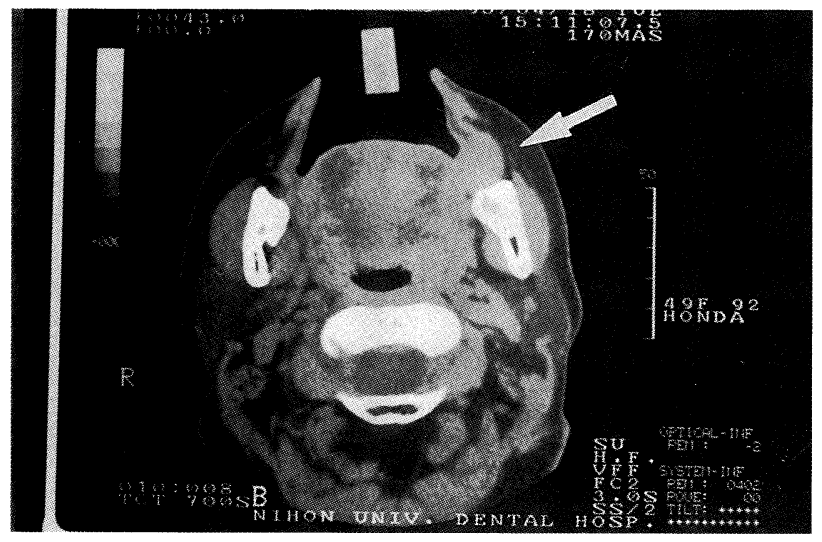

Fig. 3 A round submucosal mass of the buccal mucosa anterior to the mandibular ramus.

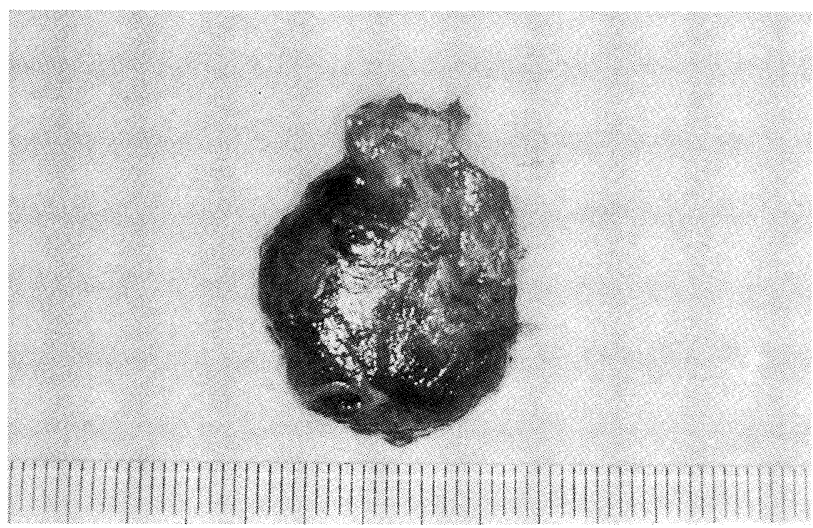

Fig. 4 Almost spherial, encapusulated excised mass.

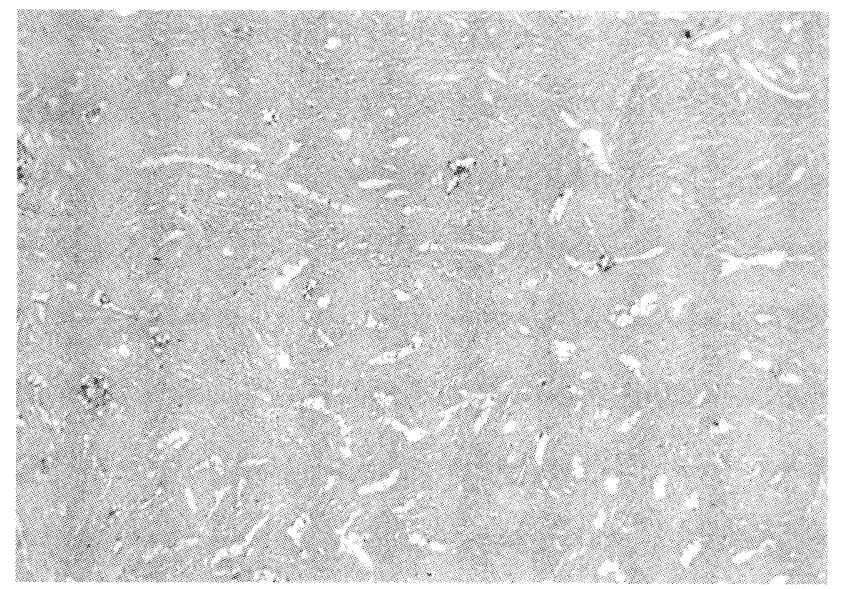

Fig. 5 Photograph of histological specimen (H-E staining). Lower magnification.

The tumor consists of proliferation and irregularshaped capilaries.
The histologic diagnosis was a benign hemangiopericytoma of the buccal mucosa. The specimens of tumor tissue showed a well circumscribed, pseudoencapsulated spindle cell lesion with prominent vascular compression or slit-like, irregularly shaped vascular spaced, lined by a single layer of flattened endothelial cells (Fig.5). The tumor cells showed spindle or oval shapes with occasional atypia (Fig.6). The lesion also contained varying amounts of fibrous-intimal proliferation. Immunohistochemical examination revealed that anti-factor VIII antibody reacted with flattened endothelial cells, but not with tumor pericytes (Fig.7). The tumor cells were not immunoreactive for smooth muscle actin or myosin (data not shown).

Follow-up evaluation at two years showed no local recurrence.

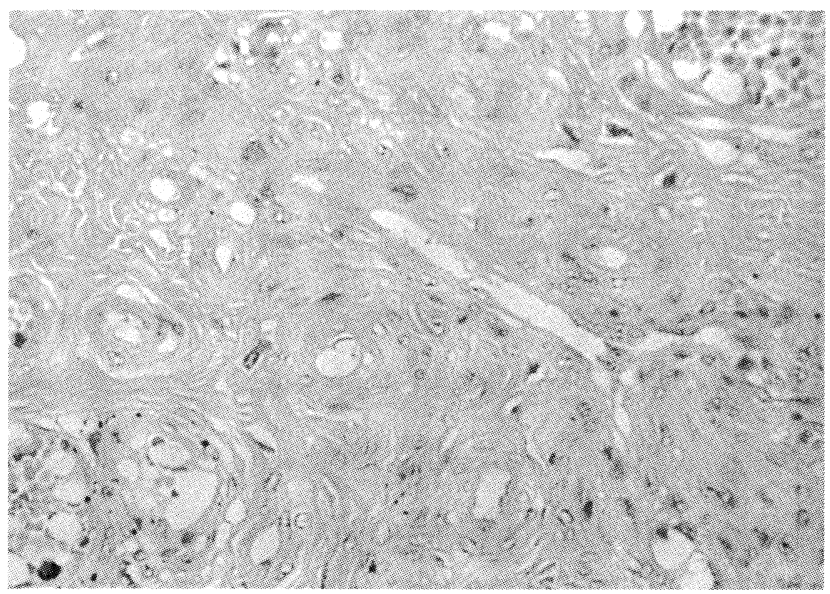

Fig. 6 Photograph of histological specimen. Higher magnification of section in fig. 5 . Spindle-shaped tumor cells showed moderate atypia and proliferated around slit-like vessels.

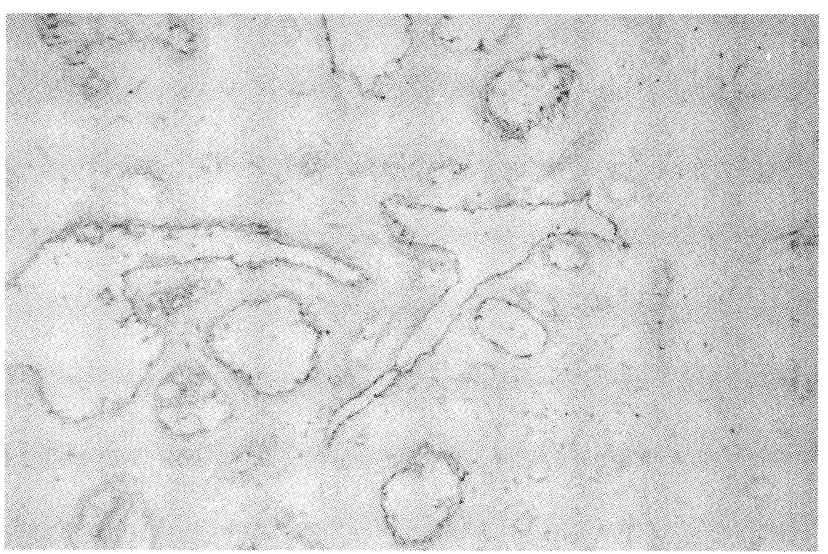

Fig. 7 Immunoperoxidase staining factor VIII. The flattened endothelial cells reveal a positive reaction while tumor cells are negative. 
Table 1 Summary of previous cases of hemangiopericytoma of the oral region in Japan

\begin{tabular}{|c|c|c|c|c|c|c|c|c|}
\hline No. & Age & Ser & size & Location & malignancy & recurrence & metastasis & Case report \\
\hline 1. & 33 & $F$ & $U N$ & Maxilla & + & + & +- & Majima et al. (1961) \\
\hline 2. & 50 & $M$ & pigeon-egg & Maxilla & - & + & - & Mukai (1964) \\
\hline 3. & 27 & $M$ & thumb's head & Lower lip & $-\cdots$ & - & - & Hayashi et al. (1968) \\
\hline 4. & 20) & $M$ & sparrow-egg & Hard palate & - & - & - & Sorimachi et al. (1970) \\
\hline$\overline{5}$ & 69 & $F$ & $U N$ & Submandibula & -+ & + & + & Kawamura et al. (1970) \\
\hline 6. & 41 & $F$ & $U N$ & Cheek & $-\cdots$ & - & - & Kotani et al. (1971) \\
\hline 7. & $4 \overline{5}$ & $M$ & hen's-egg & Floor of the mouth & + & + & + & Matsuda et al. (1973) \\
\hline 8. & 24 & $F$ & $U N$ & Mandible & + & - & - & Mizuno et al. (1974) \\
\hline 9. & 22 & $M$ & child's fist & Tongue & - & $U N$ & $U N$ & Miyagishima et al. (1977) \\
\hline 10. & 45 & $F$ & walnut & Tongue & - & - & - & Hisaeda et al. (1977) \\
\hline 11. & 13 & $F$ & child's fist & Cheek & + & + & + & Denpouzi et al. (1977) \\
\hline 12. & 37 & $M$ & walnut & Floor of the mouth & -- & - & - & Nagatani et al. (1983) \\
\hline 13. & 46 & $F$ & $35 \times 40 \mathrm{~mm}(\boldsymbol{p})$ & Mandible & + & - & - & Endo et al. (1985) \\
\hline 14. & 48 & $M$ & $15 \times 15$ mIII $(s)$ & Mandible & -- & - & - & Iwasaki et al. (1985) \\
\hline 15. & 11 & $F$ & soybean & Lower lip & - & - & - & Seno et al. (1988) \\
\hline 16. & 53 & $F$ & $\phi 25$ шाш (s) & Cheek & - & - & - & Nakajima et al. (1988) \\
\hline 17. & 33 & $M$ & $U N$ & Multiple & -1 & - & - & Nagamine et al. (1989) \\
\hline 18. & 54 & $F$ & thumb's head & Cheek & -- & -- & - & Asahi et al. (1989) \\
\hline 19. & 54 & $F$ & $11 \times 10 \mathrm{~mm}(\boldsymbol{s})$ & Upper lip & - & - & 一 & Nakajima et al. (1990) \\
\hline 20. & 74 & $M$ & $22 \times 17 \mathrm{~mm}(\boldsymbol{m})$ & Hard palate & + & - & - & Miura et al. (1990) \\
\hline 21. & 53 & $M$ & $U N$ & Maxilla & - & - & - & Ishikura et al. (1992) \\
\hline 22. & 14 & $F$ & $U N$ & Submandibula & - & - & - & Kanekawa et al. (1993) \\
\hline 23. & 1.8 & $F$ & $U N$ & Lower lip & - & - & - & Imai et al. (1994) \\
\hline 24. & 5 & $F$ & $U N$ & Cheek & - & - & - & Shirosaki et al. (1996) \\
\hline 25. & 77 & $F$ & $\phi 12 \mathrm{~mm}(\boldsymbol{s})$ & Upper lip & - & - & - & Sonobe (1996) \\
\hline 26. & 23 & $F$ & $37 \times 35$ mाm $(p)$ & Cheek & $\cdots$ & - & - & Saito et al. (1996) \\
\hline 27. & 52 & $F$ & $43 \times 33 \times 16 \mathrm{~mm}(\boldsymbol{p})$ & Cheek & - & - & - & Yanagii et al. (1996) \\
\hline
\end{tabular}

UN : unknown

(p) : corresponding to pigeon-egg size

(s) : corresponding to soybean size

\section{Discussion}

This report, has described an unusual hemangiopericytoma that occurred in the oral cavity.

Hemangiopericytoma is composed mainly of pericytes, the specific cell type first identified by Zimmermann (31). The tumor is closely related to the glomus tumor, which is also derived from pericytes (2). However, the hemangiopericytoma did not have the usual highly organized structure (1). Hemangiopericytoma is primarily a tumor occurring in adults, and is rare in children (13). The tumor occurs in both sexes with equal frequency(13).

Backwinkel et al. (4) reviewed 237 cases of hemangiopericytoma and found a high incidence in the fifth and sixth decades. One hundred twelve $(47.3 \%)$ patients were male and $125(52.7 \%)$ were female.

Suzuki et al. (2) reviewed 88 Japanese cases of hemangiopericytoma and described the presence of the tumor in all age groups, from infancy to the seventh decade. The tumor was more frequent in males $(59.3 \%)$ than in females $(40.7 \%)$ in their series.

Hemangiopericytoma can appear at any site where blood vessels are present (2). The tumor is commonly observed in the pelvic cavity and limbs, but not frequently in the oral cavity (10-20\%) of all cases $(2,4,13)$. 
We analyzed 27 cases of hemangiopericytoma occurring in the oral cavity collected from the Japanese literature (Table 1) (3,5-30). The tumor revealed a wide distribution in patient age from 21 months to 77 years with a mean of 38 years. Ten patients $(37.0 \%)$ were male and $17(63.0 \%)$ were female. Thus, the tumor did not appear to be age-related, and was more prevalent in females than in males. The most frequent site of tumors in the oral cavity was the buccal mucosa $(26.0 \%)$, followed by the maxilla $(11.1 \%)$, mandible $(11.1 \%)$, lower lip (11.1\%), hard palate (7.4\%), submandibular region $(7.4 \%)$, floor of the mouth $(7.4 \%)$, tongue (7.4 $\%)$, upper lip (7.4\%), and multiple regions (3.7\%).

Most of the patients with this tumor complained of a slowly enlarging painless mass that had usually reached a fairly large size by the time treatment was sought (34).

Suzuki et al. (2) reported that these tumors showed partial infiltration into the surrounding tissue, forming indistinct tumor margins. In the oral cavity, hemangiopericytoma was generally smaller in size than those at other sites (15). We analyzed 18 cases of oral tumor that varied from soybean-sized to the size of a child's fist, but the majority were smaller than a pigeon's egg.

As for other clinical manifestations of this lesion, tenderness and pain were infrequent, but were sometimes evident upon movement or compression (34). Thus, the clinical diagnosis of these tumors was fairly difficult (7).

The X-ray features were not specific and consisted merely of a radiopaque soft tissue mass displacing the neighboring structures. Angiography was rather useful for diagnosis in some cases (34). We applied computed tomography for our case, and the lesion showed the same density as muscle, but had a distinct border.

Histopathologically, hemangiopericytoma has characteristic vascular features consisting of anastomosing vessels of varying caliber (32). Tightly packed tumor cells proliferate around thin-walled, vascular canals lined by a single layer of endothelium, ranging from capillary-sized vessels to large sinusoidal spaces. The tumor cells have oval nuclei and indistinct cytoplasm.

However, in addition to the typical vascular pattern, dense fibrosis of the tumor matrix, marked dilatation of sub-capsular spaced vascular channels and myxoid changes resembling myxoid liposarcoma are seen in some cases. In malignant hemangiopericytoma, the tumor tends to be more cellular with cellular pleomorphism and mitotic activity.

The present tumor showed an atypical vascular pattern with vascular walls lined by a single layer of endothelium. The tumor cells revealed slight to moderate degrees of pleomorphism, but mitotic figures in the nuclei were rare. Focal fibrosis was present in the peripheral area of the tumor. Thus, our case was diagnosed as benign. Among the 27 reported cases of oral hemangiopericytoma, $19(70.4 \%)$ were histopathologically benign and $8(29.6 \%)$ were malignant.

Batsakis et al. (33) described the following clinical features which suggested malignancy : (1)a tumor diameter of $6.5 \mathrm{~cm}$ or greater, (2) tumor location in the retroperitoneum, extremities, or trunk, and (3) tumor necrosis and hemorrhage.

The primary treatment of hemangiopericytoma has been surgical resection, while radiotherapy and chemotherapy are less effective $(6,15)$. The peak time of recurrence is approximately 5 years after surgery, and 24 $\%$ of recurrences occur within one year (4). Among the 27 cases surveyed in the literature, 21 patients $(77.8 \%)$ underwent surgical resection, $3(11.1 \%)$ underwent a combination of surgical resection, chemotherapy and radiotherapy, $2(7.4 \%)$ received radiotherapy alone and only one $(3.7 \%)$ received a combination of chemotherapy and radiotherapy. All the benign cases were surgically resected.

In the present case, the tumor was resected as a single mass, and found to be benign. As a matter of caution, the tumor location and clinical characteristics $(2,4)$ of each hemangiopericytoma need to be followed up.

\section{Summary}

We have reported a case of hemangiopericytoma that developed in the left buccal mucosa of a 46-year-old woman. The findings in this case were discussed with respect to previous reports in the Japanese literature.

\section{References}

1. Stout, P. M. and Murray, M. R. (1942) Hemangiopericytoma. A vascular tumor featuring Zimmermann's pericytes. Ann. Surg. 116, 26-33

2. Suzuki, H., Sato, T., Onodera, T. and Kasai, M. (1976) Hemangiopericytoma. The present case and 86 cases reported in Japan. Jpn. J. Cancer Clin. 22, 890898 (in Japanese)

3. Mukai, H. (1964) Epuhrisujoh wo teishita kekkanshuhhishu no ichi rei. J. Otolaryngol. Jpn. 67, 1241 (abstract) (in Japanese)

4. Backwinkel, K. D. and Diddams, J. A. (1970) Hemangiopericytoma. Report of a case and comprehensive review of the literature. Cancer 25, 896-901

5. Majima, T., Hirano, T., Honda, H., Fujii, S. and Abe, K. (1961) Johgaku ni hasseishi fukubushozohki-nado ni teni-shita kekkanshuhhishu no ichi bohkenrei. J. Jpn. Soc. Intern. Med. 50, 633 (abstract) (in Japanese)

6. Hayashi, S., Ohura, S., Shimizu, H. and Goto, A. (1968) A case of the hemangiopericytoma of the lower lip. J. Jpn. Stomatol. Soc. 17, 685-689 (in Japanese)

7. Sorimachi, M. and Suda, H. (1970) A case of hemangiopericytoma of the hard palate. Jpn. J. Oral Maxillofac. Surg. 16, 32-34 (in Japanese)

8. Kawamura, S., Iimura, A., Otsuka, S. and Tani, H. (1970) Kekkanshuhhishu no ichi rei. J. Otolaryngol. Jpn. 73, 110 (abstract) (in Japanese)

9. Kotani, A., Nagauchi, T., Tsutsui, N., Morita, T. and Yamazaki, S. (1971) Kyohbu ni hasseishita kekkanshuhhishu no ichi rei. Jpn. J. Oral Maxillofac. Surg. 17, 676(abstract) (in Japanese)

10. Matsuda, N., Kato, J. and Imai, S. (1973) Oral malignant hemangiopericytoma. Report of a case with autopsy findings. Jpn. J. Oral Maxillofac. Surg. 19, 
477-479 (in Japanese)

11. Mizuno, Y., Goto, Y., Esumi, K. and Tawara, E. (1973) Kagaku ni hasseishita kekkanshuhhishu to omowareru ichi rei. J. Jpn. Stomatol. Soc. 22, 259 (abstract) (in Japanese)

12. Miyagishima, T., Sanshina, M. and Makita, K. (1977) Zetsu ni hasseishita kekkanshuhhishu no ichi rei. J. Jpn. Stomatol. Soc. 23, 324 (abstract) (in Japanese)

13. Hisaeda, K., Wada, T., Shirasuna, K., Uchihashi, T., Hasegawa, K., Sakuda, M., Machida, J. and Miyazaki, T. (1977) A case of hemangiopericytoma of the tongue. Jpn. J. Oral Maxillofac. Surg. 23, 778-782 (in Japanese)

14. Denpouya, C., Mori, F., Mikami, H., Kodera, M., Kita, S. and Suzuki, M. (1977) Kyohbu ni shuryuh wo tsukkuta akuseikekkanshuhhishu no ichi rei. J. Michinoku Dent. Soc. 8, 40-42 (in Japanese)

15. Nagatani, Y., Sugihara, K. , Tomori, Y., Fujisaki, M., Nakamura, S., Soejima, K., Seguchi, Y. and Yamashita, S. (1983) A case of hemangiopericytoma in the floor of the mouth. Jpn. J. Oral Maxillofac. Surg. 29, 1429-1432 (in Japanese)

16. Endo, Y., Numata, M., Moriya, Y., Ohmura, T. , Hayashi, S., Matsuda, K. and Yamamoto, H. (1985) Malignant hemangiopericytoma of the mandibular alveolar process. Jpn. J. Oral Maxillofac. Surg. 31, 1476-1482 (in Japanese)

17. Iwasaki, H., Shimada, Y., Muraishi, M. and Akasaka, Y. (1985) Kekkanshuhhishu no ichi rei. J. Jpn. Stomatol. Soc. 34, 882 (abstract)(in Japanese)

18. Seno, K., Yajima, Y., Kakizawa, T., Noma, H. , Hamano, H., Hashimoto, S. and Shimono, M. (1988) A case of hemangiopericytoma of the lip. Jpn. J. Oral Maxillofac. Surg. 34, 2901-2902 (in Japanese)

19. Nakajima, K. , Fukuda, T. and Ida, M. (1988) A case of cheek hemangiopericytoma with application of plastic surgery. Jpn. J. Oral Maxillofac. Surg. 34, 1655-1662 (in Japanese)

20. Nagamine, S., Iga, H., Miyamoto, K., Azuma, M. , Segawa, T., Warido, A., Yoshida, H. and Sato, M. (1989) Kohhan na shinten wo mita kohkuhakuseikekkangaihhishu kanja ni okeru IVH no keiken. Jpn. J. Surg. Metab. Nutr. 23, 191 (abstract) (in Japanese)

21. Asahi, M., Takata, T., Ogawa, I., Nomura, M., Ito, H., Ijuin, N. and Nikai, H. (1989) A case of hemangiopericytoma of the buccal mucosa. An immunohistochemical and ultra structural study with review of the literature. Jpn. J. Oral Maxillofac. Surg. 35, 1935-1940 (in Japanese)

22. Nakajima, Y., Tanaka, S., Namekawa, T., Toyofuku, T., Ohgi, T. and Kanayama, T. (1990)
Johshinnenmakubu ni mirareta ryohseikekkanshuhhishu no ichi rei. Jpn. J. Oral Maxillofac. Surg. 36, 2974 (abstract) (in Japanese)

23. Miura, N., Hanzawa, M. , Shirai, Y., Nakamura, H. , Notani, K., Tozuka, Y., Fukuda, H., Shindo, M., Iizuka, T., Mukaugo, T. and Amamiya, A. (1990) A case of malignant hemangiopericytoma of the hard palate. Jpn. J. Oral Maxillofac. Surg. 36, 220-221 (in Japanese)

24. Ishikura, N., Ryoke, K. , Takahashi, K., Fukumoto, J., Tanio, K. and Hamada, T. (1992) Kagakushi-naisoku no kohkaseikekkanshu tekishutsushohrei ni mirareta johgaku(dohsoku) no kekkanshuhhishu no ichi rei. Jpn. J. Oral Maxillofac. Surg. 38, 2247 (abstract) (in Japanese)

25. Kanekawa, A., Kamimura, T. and Kamei, T. (1993) Gakkabu ni hasseishita kekkanshuhhishu no ichi rei. J. Jpn. Stomatol. Soc. 42, 625 (abstract) (in Japanese)

26. Imai, T., Ohtani, T., Kato, M., Kamiya, Y. and Ono, K. (1996) A case of hemangiopericytoma of the lower lip. Jpn. J. Oral Maxillofac. Surg. 42, 91-93 (in Japanese)

27. Shirosaki, N., Noguchi, S., Imamura, H. , Kubota, H, Goto. , M. and Kozuki, T. (1996) A case of hemangiopericytoma of the cheek in a child. Jpn. J. Oral Maxillofac. Surg. 42, 1206-1208 (in Japanese)

28. Sonobe, M., Tuji, T., Fukuda, H., Shindo, M. and Kogo, T. (1996) Johshin ni hasseishita kekkanshuhhishu no ichi rei. J. Jpn. Stomatol. Soc. 45, 758 (abstract) (in Japanese)

29. Saito, T., Fukuda, Y., Ogawa, J., Ishikawa, Y., Sato, K. and Kudo, K. (1996) A case of buccal hemangiopericytoma. Jpn. J. Oral Maxillofac. Surg. 42, 1070-1072 (in Japanese)

30. Yanagii, T., Suzuki, S., Koike, K., Shirakawa, M., Fujita, H. and Nonaka, H. (1996) A case of hemangiopericytoma of the cheek. Jpn. J. Oral Maxillofac. Surg. 42, 1529-1530 (in Japanese)

31. Zimmermann, K. W. (1923) Der feinere Bau der Blutcapillaren. I. Die Endothelzellen. Z. Anat. Entwicklungsgesch. 68, 29-48

32. Enzinger, F. M. and Weiss, S. W. (1983) Soft tissue tumors. Hemangiopericytoma. The C. V. Mosby, London, 463-475

33. Batsakis, J. G. and Rice, D. H. (1981) The pathology of head and neck tumors : vasoformative tumors, part 9B. Head Neck Surg. 3, 326-339

34. Usui, Y., Totsuka, Y., Notani, K., Fukuda, H., Sato, K., Shindo, M. and Amemiya, A. (1987) A case of malignant hemangiopericytoma of the parotid gland. Jpn. J. Oral Maxillofac. Surg. 33, 70-75 (in Japanese) 